\title{
PROMOTING CULTURAL AWARENESS THROUGH INTERCULTURAL LISTENING ACTIVITIES
}

\author{
Arini Nurul Hidayati ${ }^{1}$ \\ arininurul@unsil.ac.id \\ Santiana ${ }^{2}$ \\ santiana@unsil.ac.id \\ Universitas Siliwangi - Tasikmalaya
}

\begin{abstract}
As diversity is one of heated issues emerging in English teaching learning circumstance in Indonesia, teachers have to initiate strategies to restrain the probability of fragment among the students which can furthermost impact on their ability to communicate among cultures. Intercultural listening activities conducted at a university in West Java has evidently proven its contribution in consolidating the students' cultural awareness. Through reflective journals and focusedgroup interviews, it is found that the students are able to discover, understand, and compare their own culture and others, realize the similarities and differences, and respect the existing gaps in between. Thus, they are presumed to be more ready to take part in the intercultural communication.
\end{abstract}

Key words: Intercultural Listening, Cultural Awareness

\section{Introduction}

A salient issue in learning any foreign language is learning its culture because language and culture are two inseparable entities, therefore, the incorporation of cultural issues in teaching language is inevitably recommended (Yeganeh and Raeesi, 2015). However, this notion becomes a great challenge in any settings in which there is no direct access to the target culture. Thus, teachers and materials being used play a very significant role in providing any cultural information. This aims at heightening students' cultural awareness and developing their sense of their own culture and the target culture (Tavares and Cavalcanti, 1996) and improving their perception of a foreign culture and their own culture by gaining awareness of a foreign language (Ritlyova, 2009). In short, cultural insertion in language teaching highly influences the students' ability to be more sensitive individuals in terms of understanding the diverse cultural issues between their own culture and the target language.

In the context of listening class in which the students are required to experience "an active process that entails construction of meaning beyond simple decoding" Namaziandost, Sabzevari, and Hashemifardnia, 2018), possessing decent cultural information about the contexts of the texts emerges as another important aspect. This aims not only to give the students clearer sense of the actual linguistic competence such as pronunciation, sentence structure, grammatical patterns, and vocabulary but also to sensitize them in predicting the 
content and the process of meaning making. Therefore, they will have competencies to response more culturally appropriate and help them develop their positive language attitude towards the target language. This is in line with Rogers and Farson (1987) which contend, "Listening builds deep, positive relationship, and tends to alter constructively the attitudes of the listeners." The way the students respond to the given materials in some certain talks would impact how they develop their future relationship with the people in the given texts. Moreover, to build a successful communication is to create a two-way process whereby the listener plays an equally important role; as it emphasizes on the speaker and its message.

Misunderstanding, especially in communication across cultures, emerging because of the inappropriate responses given by the listener can actually be minimized. In listening classroom context, teachers can optimize the suitable approach to get the students ready in that sort of communication. Intercultural approach is one best solution to help students prepare intercultural communication readiness. In this context, the students are required into activities regarding the given topic which contain intercultural contents. The teachers facilitated them with any valuable sources such as YouTube, Radio Announcement, TV program, and short movies. This would lead them into crushing of shortcomings that possibly appear while communicating.

The concept of listening will impact on the specifics of information processing, on monitoring information, and on behavior regulation (Fitzgerald \& Cunningham, 2002; Imhof \& Janusik, 2006; Kruglanski, 1996). This is consistent with the notion that culture influences how the students listen and for what they listen (Gudykunst, 1998; Gudykunst \& Matsumoto, 1996). Intercultural listening, in this case, is created situations in classroom context to provide students with listening activities involving various background of speakers from around the world (Brazil, Singapore, Japan, India, Spain, France, etc.).

Intercultural Approach which promotes the students to become cultural diplomats has predominantly given direct effect to both the students and teachers. These effects then evidently promote valuable conception and experience for the students As a teaching guidance, the teachers refer to modified listening syllabus by themselves based on Intercultural Task Design by Byram (2002).

Table 1

Intercultural Task Design (Byram, 2002)

\begin{tabular}{|c|c|c|c|c|}
\hline Goals & Input & Learners' Role & $\begin{array}{c}\text { Teachers' } \\
\text { Role }\end{array}$ & Settings \\
\hline
\end{tabular}


1) To investigate how everyday conversation maintains the solidarity of social groups;

2) to invistigate how the individual's status in a group is negotiated through casual conversation;

3) to observe the difference roles played by men and women in conversation in the target culture;

4) to explore the cultural message conveyed by visual images, literary, and media text.
1) spoken text for discussion

2) visual images for interpretati

on
1) Negotiator

2) Mediator

2) organizer

3) evaluator

4) reporter

5) reconstructor
1) Individu

al work

2) Peer work

3) Group work

4) Whole class activity

Previous studies in the area of cultural integration in listening comprehension have been conducted. Kusumarasdyati (2005) investigated the use of presentation of movies as English listening activity in the context of tertiary education in Indonesia to incorporate the target culture. This research concludes that this technique is effective to develop students' listening skill and sensitize them to the target culture which is inseparable aspect of language learning. Moreover, Mahmoudi (2017) found out the probable relationship between listeners' cultural schemata and its activation and their performance in EFL (English as a Foreign Language) listening comprehension in the Iranian context. The theory of the investigation was acknowledged suggesting that a new content, regardless of whether it is theoretically comparable, cannot activate a culturally recognizable schema in the low-level learners. Recently, Namaziandost, et al. (2018) explores the effect of cultural materials on listening comprehension in an EFL Iranian context, focusing on both male and female genders. Meanwhile, the present study will particularly focus on investigating what aspects of cultural awareness that have been developed during intercultural listening class activities for a semester through reflective study and stimulated recall interviews.

\section{Methodology}

This research employs reflective framework and interview-based study. In teaching and learning context, to reflect means to sum up, evaluate, and replan new action regarding to the whole process of implemented activities. It is in line with Check and Mc.Entee's statement (2003), “....reflective teaching is peelin back the layers of our own daily work, looking under the surface of our own teaching, making a conscious attempt to see our teaching selves as students see us, or as an observer in our classrooms would. Rushton and Suter (2012) add "...reflective practice is concerned with the teacher thinking, meditating or pondering over the day, the last session, the needy student at break-time, the fruitful discussion that came out of the risky newspaper article and the waiting marking pile, etc." In the other hand, reflective practice is concerned with the daily practice, challenges, and triumphs of the teachers' efforts. It is efforts done by the teachers to rectify 
teaching quality in order to yield qualified output. Moreover, Ryan and Ryan (2015) strengthen, that reflective practice "includes two key elements: (1) making sense of experience; and importantly, (2) reimagining future experience." This definition reflects the belief that reflection can operate at a number of levels, and suggests that to achieve the second element (reimagining), one must reach the higher, more abstract levels of critical reflection.

Innovative teachers put reflective teaching in a vital position for any reasons. It also one factor which determines the success of teaching and learning process. Rushton and Suter (2012) mention that "there are many reasons for reflecting on practice and it is useful for our purposes here to group them into three categories: improving and developing teaching and learning; accommodating change; and complying with regulatory systems." Therefore, it is necessary to apply reflective practice to both the students and teachers. Loughran (2006) finally concludes, "reflection is something that when understood and valued (by teacher educators and student-teachers) that can be developed through teacher education programs where teacher educators practice what they preach." Bain et al (2002) designed conceptual framework of reflective teaching into 5Rs; reporting, responding, relating, reasoning, and reconstructing. The following table explains the details:

Table 2

Reflective Teaching Model (Bain et al., 2002)

\begin{tabular}{|c|c|}
\hline 5Rs & Descriptions \\
\hline Reporting & $\begin{array}{l}\text { A brief descriptive account of a situation / issue (ie. the } \\
\text { reflective trigger) What happened, what the situation / } \\
\text { issue involved }\end{array}$ \\
\hline Responding & $\begin{array}{l}\text { Your emotional / personal response to the situation / issue, } \\
\text { etc. Your observations, feelings, questions about the } \\
\text { situation / issue }\end{array}$ \\
\hline Relating & $\begin{array}{l}\text { Personal and/or theoretical understandings relevant to the } \\
\text { situation / issue, making connections between the } \\
\text { situation / issue and your experience, skills, knowledge } \\
\text { and understanding }\end{array}$ \\
\hline Reasoning & $\begin{array}{l}\text { Your explanation of the situation / issue explaining the } \\
\text { situation/issue in terms of the significant factors, relevant } \\
\text { theory and/or experience }\end{array}$ \\
\hline & Drawing conclusions and developing a future action plan \\
\hline Reconstructing & $\begin{array}{l}\text { Your deeper level of understanding about the situation / } \\
\text { issue that is used to reframe / reconstruct your future } \\
\text { practice and further develop your understanding of } \\
\text { professional practice }\end{array}$ \\
\hline
\end{tabular}

This research was conducted throughout a semester in four listening classes at a university in Tasikmalaya, West Java. The participants of this research are two English teachers and their students. The total number of the students is 132, 95 females and 37 males. Empirical data were collected through focused group interviews and documentation of the teachers' reflective journal. The obtained data were analysed through thematic analysis which aims at identifying, 
analyzing, and reporting patterns within obtained data (Braun \& Clarke, 2006). This analysis embraced familiarization with data, generating initial codes, searching for themes among codes, reviewing themes, defining and naming themes, and producing the final report (Braun \& Clarke, 2006). Thus, the data were categorized and coded based on recurring themes, which represented data sets relevant to specific research question.

\section{Findings and Discussion}

\section{Developing Students' Discovery and Understanding of their Own Culture}

Every EFL student belongs to a certain cultural community which has particular values, beliefs, and norms. It influences the way they think, communicate, and interact with their society. Frank (2013) maintains that the ability to ask and answer questions based on the self-culture facilitates the process of making connections with other cultures. In the reflective journal, the teacher reveals,

Today I have given a video about the culture of Indonesia which was taken from Pesona Indonesia channel on YouTube. It showed about the diversity of Indonesian vibrant cultures from Sabang until Merauke, especially in relation to the traditional customs. The narrator of the video was an American native speaker with had a very clear accent which is easy understandable. His pronunciation is acceptable and the speed rate is also easy to follow. After watching the video twice, I invited the students to discuss the video. I asked them to give their ideas about those cultural diversities. They were very enthusiastic in giving opinions even though there were still two or three of them who seemed reluctant to contribute, but overall most of them were very open-minded and had a quite broad knowledge about the Indonesian traditional customs, especially when they related the events in the video with their own local customs.

(Teacher's journal written in April 2015)

The excerpt gives an explanation that the teacher had activated the students' awareness of their own culture by providing learning material and follow-up activity which explored their knowledge about the culture of Indonesia. This activity facilitates the emergence of self-discovery of their local cultures. Byram (1997) supports that "English teachers can help the students activate their cultural antennas by making them aware of important elements of their own culture and helping them understand how their culture has shaped them." Depicting this situation, Kramsch (1999) calls this learning process establishing a 'sphere of interculturality'. It means that the teacher had maintained and inserted the cultural aspects in their teaching which triggered the students to discover and understand their own culture.

The students' openness to visit their local customs has contributed positively towards their cultural awareness during listening activity. Furthermore, 
this also contributes significantly on their real life listening. Through focused group interviews, the students explain their feeling and experiences,

"The activities in listening class had opened my horizon about the difference in the world. I learn English but I also become more aware to be an Indonesian." (Student 12; taken in December 2015)

"The activities had given very positive impact on my self-confidence when practicing my English in study tour in Bali. I felt braver to speak with foreigners because I realized that I am not a native speaker, so I still felt satisfied to be brave enough to talk to them even though my English was not really good." (Speaker 20, taken in December 2015)

The students' perception on the listening activity above proves the notion that EFL learners can still grasp the values that exist in the target culture even though the culture is not taught explicitly in the class (Lessard-Clouston, 1997). Therefore, it is undoubtedly that culture is the heart of the foreign language instruction (Herron et al., 2002). However, there are situations that required certain attention to overcome in which open minded and explicit learners usually show high awareness and readiness toward the target culture and the language learning process, while some implicit and ego-centered learners show reluctant to the cultural awareness activities. Therefore, teachers need to consider the appropriate technique to cover both learners' characteristics. In another page of the teacher's journal, she mentioned the condition,

Facing active and enthusiastic students is usually easier than those who tend to be silent. Sometimes it requires more attention and energy to dig what are happening. Today I was just aware that there was one student who was always hard to convey her ideas. At the beginning, I always triggered her by giving questions in discussion sessions after listening activity but she tended to doubt to answer. Later, I asked her personally and I found out much information about her personal and social background afterwards. She comes from a marginalized ethnic in our city and always feels patronized. However, after having a long conversation with her, I could say that she really had a very strong sense of her own community and culture. She even could explain in detail about the videos that we have learned during the meetings and connected the contents with her own contexts.

(Teacher's journal written in April 2015)

The condition supports the notion of Kramsch (1993) which underlined that culture in language learning is always in the background in classrooms when language students are searching for a good communicative ability and exhorting their capacity to comprehend their general surroundings. Even though this type of student shows less enthusiasm in the whole class activity, but since intercultural listening class allows the individual mediated setting (see Byram, 2002), thus, the 
teacher implemented the task in a different way. Therefore, the students still can contribute and engage to the listening learning activities. This revealed that the more participants were subjected to familiarity to cultural knowledge of the language, the more they enhanced their listening comprehension (Namaziandos, 2018).

\section{Building Students' Respect on the Culture of 'Others'}

Byram (1997) suggests that people who are "interculturally competent" will have a solid understanding of their own culture and how it has shaped them, and make connections between how cultural elements manifest in behaviors across cultures. This notion has brought the learning activities in the listening class into variety of intercultural tasks, presented the intercultural materials and sources, and modified any intercultural settings. From the teacher's journal, it can be seen,

“...the material for today is about the future plans. I took two videos from YouTube as the listening sources. The first video is two Indian people talking about their plan for future marriage. The second is two Japanese people talking about their holiday. Both videos have high level of difficulty in terms of understanding because the speakers performed their English pronunciation with their local language interference." (Teacher's journal written in May 2015)

The teachers challenge the students by showing those videos "hoping to help their students become interculturally competent through building a "culturally friendly" classroom (Frank, 2013). However, providing intercultural activities might also impact on the students experiencing culture shock, cultural adaptation, cultural adjustment, and the fact that people from other cultures may interpret similar situations differently (Cohen et al., 2003) in Frank (2013). Some interview results inform,

"To me, it is extremely difficult to get the messages from the English speakers with strong Indian and Japanese accents. I need to listen to the videos more than three times."

(Interview results from student 2, 3, 6, 7, and 10; December, 2015)

"The challenging issue after pronunciation is their gestures. Indian people in the video shown for example, they do headshakes many times. Sometimes it is difficult to interpret when they really say 'no'."

(Student 40, December 2015)

"It makes me dizzy and somewhat confused, because it is my first time listening to non-British and American English accents." 
(Student 22, December 2015)

This considers as a good starter for the process of acculturation into a new culture in order to build the students' appreciation on the culture of others. Acculturation, according to Brown, et al. (1994), has four stages: (1) excitement (about being in a new country), (2) culture shock (feelings of frustration and hostility), (3) recovery (adjustment and emergent comfort in the new culture), and (4) adaption (bridging cultural barriers and accepting the new culture). Therefore, by providing such experience in the classroom activity, the students are expected to feel they are starting some new cultural journeys and start to have knowledge about other people's cultures.

In the following days, the students performed better readiness to experience other intercultural journeys in different listening activities which result in the raising of their cultural awareness,

"This class has given me a lot of benefits especially on the increase of my knowledge about different accents and the culture from people in different English speaking countries."

(Student 18, December 2015)

"Every activity in this class prepares me to be ready for doing intercultural communication. I feel more passionate to search more information about the cultures from different countries."

(Student 11, December 2015)

The activities allow students to experience any intercultural journeys even though many of them might never have direct contact with the English language speakers. Frank (2013) mentions that students who may never travel outside their country or even meet an English language speaker might question why they need to study culture. However, as the world becomes more interconnected, the teacher must help their students understand that it is more important than ever for them to be able to activate their "cultural antennas" to understand not only other cultures, but their own as well. In doing so, they will be better prepared to participate more fully in the global communication.

\section{Conclusion}

Preparing students to be an intercultural communicator is very crucial in the recent teaching trend. It can be initialized through classroom experience in order to create their readiness for communicating among cultures. The first stage is by introducing them into various situations set in the listening class. Authentic materials, intercultural mediated setting, and follow-up discussion sessions are the examples of the actions that can be utilized to promote the students' cultural awareness. From these activities, the students revealed their positive arguments through the reflective process due to this teaching activity. Their cultural 
awareness has developed and they are more ready to get involved into the real life communication. Thus, the intercultural listening activities are extremely beneficial and recommended to implement in listening class. Other researchers can implement this approach not only in listening class, but also in other English skill classes.

\section{References}

Bain, J. D., Ballantyne, R., Mills, C., \& Lester, N. C. 2002. Reflecting on ractice: Student Teachers' Perspectives. Flaxton: Post Pressed.

Bonvillain, Nancy. 2013. Language, Culture, and Communication. Pearson Education Ltd. London.

Braun, V. and Clarke, V. 2006 Using thematic analysis in psychology. Qualitative Research in Psychology, 3 (2). pp. 77-101. ISSN 1478-0887 Available from: http://eprints.uwe.ac.uk/11735

Brown, C. H., Callaghan, C. A., Casson, R. W., Etxebarria, J. M., Hill, J. H., Lehman, F. K., ... \& Proulx, P. (1994). Lexical Acculturation in Native American Languages [and Comments and Reply]. Current Anthropology, 35(2), 95-117.

Byram, M. 1997. Teaching and assessing intercultural communicative competence. Multilingual Matters.

Byram, M. 2002. Developing the Intercultural Dimension in Language Teaching. Strasbourg: Council of Europe.

Check, Joseph W. et al. 2003. At the Heart of Teaching: A Guide to Reflective Practice. Teachers College Press: New York.

Corbett, John. 2003. An Intercultural Approach to English Language Teaching. Great Britain: Cromwell Press Ltd.

Hill, Jonnie Lynn. 2006. Adventures in Intercultural Listening. Unpublished: Oklahoma University.

Herron, C., Dubreil, B., Corrie, C., \& Cole, S. P. 2002. A Classroom Investigation: Can Video Improve Intermediate-Level French Language Students' Ability to Learn about a Foreign Culture?. The Modern Language Journal, 86(1), 36-53.

Frank, J. 2013. Raising Cultural Awareness in the English Language Classroom. In English teaching forum (Vol. 51, No. 4, p. 2). US Department of State. Bureau of Educational and Cultural Affairs, Office of English Language Programs, SA-5, 2200 C Street NW 4th Floor, Washington, DC 20037.

Kramsch, Claire. 1998. Language and Culture. Oxford University Press: Hongkong.

Kramsch, C. 1999. Thirdness: The intercultural stance. Language, culture and identity, 41-58.

Lessard-Clouston, M. (1997). Towards an understanding of culture in L2/FL education. The Internet TESL Journal, 3(5), 12. 
Loughran, J. John. 2005. Developing Reflective Practice. The Falmer Press: Bristol. and Margaret Imhof. 2016. Intercultural Listening: Measuring Listening Concept with the LCI-R. International Journal of Listening. [Retrieved on July 23, 2016]

Namaziandost, E., Sabzevari, A., \& Hashemifardnia, A. 2018. The effect of cultural materials on listening comprehension among Iranian upperintermediate EFL learners: In reference to gender. Cogent Education, 5(1), 1560601.

Ritlyová, A. 2009. Cultural Studies in Language Teaching. In Language, Literature and Culture in a Changing Transatlantic World, International Conference Proceedings, April 22-23 2009 (pp. 93-97).

Rogers, Carl R. and Richard E. Farson. 1987. Active Listening. Retrieved from: www.gordontraining.com [online August 2, 2016]

Rushton, Ian and Martin Suter. 2012. Reflective Practice for Teaching in Lifelong Learning. Bell and Bain, Ltd.: Glasgow.

Ryan, Maria Elizabeth. 2015. Teaching Reflective Learning in Higher Education. Springer: Queensland.

Tavares, R., \& Cavalcanti, I. 1996, July. Developing cultural awareness in EFL classrooms. In English Forum (Vol. 34, No. 3, pp. 1-18).

Yeganeh, M. T., \& Raeesi, H. 2015. Developing cultural awareness in EFL classrooms at secondary school level in an Iranian Educational context. Procedia-Social and Behavioral Sciences, 192, 534-542. 